\title{
Magherescu, Delia: \\ Drept procesual penal: Partea generală: Partea specială [Criminal Procedure Law: General Part: Special Part]. Bucureşti: Pro Universitaria, 2020.412 p. ISBN 978-606-26-1267-2
}

\section{Djulieta Vasiloi}

Abstract: Reviewing the publication Magherescu, Delia: Criminal Procedure Law: General Part: Special Part, a significant legal education instrument addressed to those who might be interested in deepening their knowledge in the field of the criminal justice system of Romania.

Key Words: Review; Scientific Publication; Criminal Law; Criminal Procedure Law; Criminal Proceedings; Ordinary Criminal Procedure; Special Criminal Procedure; Romania.

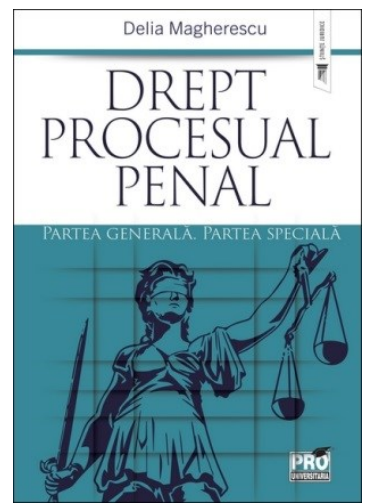

Understanding legal provisions which regulate the organization of judicial activities of both investigation bodies and courts of law in criminal matters as well as the development of the criminal proceedings in the framework, terms and procedures provided by the Code of Criminal Procedure means imperatives for the practitioners in the field of judiciary. Equally, such rules of the criminal proceedings should be deepened by students of the faculties of law, in order for them to advance their own principles, opinions and ideas, argued scientifically, that must conduct to a better application of the procedural norms in practice in the future.

The widespread area of criminal procedure law creates, in such circumstances, the possibility for a future practitioner who will practise as a lawyer to evaluate the theses stated by the legislator, to comment pertinently the jurisprudence provided in this field as well as to explain the own theories, with reference to the legal doctrine. In order to achieve these perspectives, first of all, the lawyers need legal instruments of 
criminal procedure law which help them to emphasize the entire institutions, procedures and legal rules in criminal matters. As for experts of law, a grounded knowledge in the field of the criminal proceedings is very necessary and assures them a successful career for the future. In this way, the new publication of the Criminal Procedure Law is devoted as an educational tool to support the students in their activities within the faculties of law as well as their specialization in legal sciences. The presented university publication, being at the first edition, was published in year 2020 in Bucharest, Romania, and is structured into the General Part and the Special Part, each of them being divided into several chapters as well.

The $1^{\text {st }}$ Chapter is devoted to the basic notions of the criminal proceedings, giving the readers aspects regarding the features of criminal procedure law, such as the autonomy, publicity and unity, which characterize this legal science across the entire judicial activities. A unique definition provided for the criminal procedure law is, in fact, impossible, due to the fact that the theoreticians specializing in criminal procedure law have their own arguments which converge to the provisions of the Romanian Code of Criminal Procedure. Thus, it is admitted one of the most relevant definitions of the criminal proceedings, which states that it is a complex activity carried out by several judicial bodies, which has as the main purpose discovering crimes and perpetrators in such a manner that all of them to be under the criminal liability in accordance with the guilt provided by the criminal law. Therefore, such a unique definition provided for the criminal proceedings cannot cover all aspects that the complex activities of a so ample concept achieve. For this reason, the interpretation of the criminal procedure rules, regulated by the Code of Criminal Procedure, occurs. Moreover, the legislator does not provide a substantive definition of the criminal proceedings, but just specifies who may exercise these activities according to the Articles 1, 7 and 10 of the Code of Criminal Procedure as well as the procedural acts that may also be carried out during the criminal proceedings.

Within the $2^{\text {nd }}$ Chapter, both criminal action and civil action of the criminal proceedings are explained. The legal background of promoting and exercising criminal action is given by committing crimes. Any infringement of the rules of substantive criminal law means a violation of the social relations protected by the criminal law, so that the judicial bodies have the main duty to identify perpetrators in purpose for them to proceed in starting formalities of exercising criminal action. Equally, 
whether the perpetrators have produced material damages or moral damages regarding the victims of crime those would like to be involved as a civil party in the criminal proceedings - then they have two legal possibilities, either choosing to claim damages during the criminal proceedings in terms and conditions stipulated by the Articles $19-25$ of the Code of Criminal Procedure, or introducing civil action within the civil court of law in purpose to obtain compensations, as it is regulated by the Article 27 thereof.

The participants in the criminal proceedings are concretized in the $3^{\text {rd }}$ Chapter and the judicial bodies' competences are approached in the $4^{\text {th }}$ Chapter. The competence of exercising judicial activities by the judicial bodies is explained from the point of view of the Code of Criminal Procedure's provisions, both in the investigation phase and the judgment phase of the criminal proceedings.

There are material, territorial and personal competences given, and in this respect, the activities carried out by the investigation bodies, prosecutors, judges of rights and freedoms, judges of preliminary courtroom and the courts of law are described in detail. On the one hand, the main processual subjects are also participants in the criminal proceedings. They refer to suspects and victims. On the other hand, parties in the criminal proceedings are defendants, civil parties and civil responsible parties, each of them being characterized by their rights and obligations as well. Last but not least, the legal assistance in the criminal proceedings represents an essential requirement of due process, called for by the European Convention on Human Rights (the Convention for the Protection of Human Rights and Fundamental Freedoms) and by the jurisprudence of the European Court of Human Rights of Strasbourg. In this matter, the High Court of Cassation and Justice of Bucharest has pronounced a decision $^{1}$ which states that the legal assistance is compulsory both for the natural person - defendants and the legal entities - defendants as well, according to the conditions stated by the Code of Criminal Procedure. ${ }^{2}$

Evidence and means of evidence are discussed within the $5^{\text {th }}$ Chapter. First of all, it should be clarified that there is a distinction between these notions, specifically in the field of evidence, which can be adminis-

1 See Decision of the High Court of Cassation and Justice of Romania Ref. No. 21/2016 [201610-11]. Official Journal of Romania, 2016, No. 884.

2 See MAGHERESCU, D. Drept procesual penal: Partea generală: Partea specială. 1-a ed. București: Pro Universitaria, 2020, p. 95. ISBN 978-606-26-1267-2. 
tered during the criminal proceedings, and the means of evidence, the main purpose of which is to find evidence. According to the Article 97 para 1 of the Code of Criminal Procedure, "evidence is every element de facto which serves to stating presence or absence of a crime, identifying perpetrator who committed that crime as well as discovering based circumstances for clarifying criminal case pertinently and which contributes to finding truth in criminal case." As for the above-stated provision, it should be concluded that the main scope of the criminal proceedings is that of finding truth regarding committing the crime and identifying perpetrator, which may be realized through gathering evidence administered during the criminal proceedings. Regarding the issue of administering evidence, the principle of loyalty of administering evidence, stipulated by the Article 101 of the Code of Criminal Procedure, is currently in force. At the same time, the Code of Criminal Procedure's provisions provide that the evidence must be pertinent, conclusive and genuine for the criminal case and must help judicial bodies to solve it legally and substantially.

The $6^{\text {th }}$ Chapter is devoted to the preventive measures and the other processual measures. Referring to the category of preventive measures, apprehension, judicial control, judicial control on bail, house arrest and preventive arrest are regulated, while the second category includes insured measures, restoration of goods and re-establishing of former situation. The preventive measures' scope is that of assuring the development of the criminal proceedings under the legality and normality in such a manner that the investigation phase and the judgment of criminal cases to be carried out by expedience. The procedure of ordering preventive measures differs from the phase of investigation to the preliminary courtroom or the judgment phase of the criminal proceedings. At the same time, the competence of ordering preventive measures is provided differently, so that the apprehension may be ordered by the prosecutors and investigation bodies during the investigation phase, while the other preventive measures may be ordered by the judge of rights and freedoms, judge of preliminary courtroom and court of law exclusively, in conformity with the stage of the criminal process. ${ }^{3}$ Regarding the ordering insured measures in cases of very serious damages, the Constitutional

3 See MAGHERESCU, D. Drept procesual penal: Partea generală: Partea specială. 1-a ed. Bucureşti: Pro Universitaria, 2020, pp. 185-187. ISBN 978-606-26-1267-2. 
Court of Romania has decided in its decision No. 96 of March 2018 that the obligatory character of those measures appears as justified. ${ }^{4}$

The aspects regarding the ordinary processual and procedural acts are presented in the $7^{\text {th }}$ Chapter. Along with the citation and communication of procedural acts, the absence of which detains the criminal proceedings, a particular attention is paid to the legal institution of nullity. ${ }^{5}$ A distinction between two kinds of nullity, regulated by the Articles 281 and 282 of the Code of Criminal Procedure as absolute nullity and relative nullity, is highlighted. The absolute nullity intervenes in cases in which the criminal provisions on composition of the court of law, material and personal competences, public courtroom session and so on are broken, while the relative nullity appears in cases of infringing other legal provisions than those applied by the Code of Criminal Procedure for cases of absolute nullity. They refer to the provisions which violate the parties' or the main processual subjects' rights.

Special Part of the reviewed publication Criminal Procedure Law is devoted to the fundamental institutions of the investigation phase, the procedure within the preliminary courtroom, the judgment in the first instance and appeals, the special procedures as well as to executing definitive judicial decisions of condemnation in criminal matters. Thus, the Special Part begins in the $8^{\text {th }}$ Chapter with an introduction which emphasizes the correlation between the general part and the special part of the criminal proceedings as well as its importance for achieving the purpose of the special part of criminal procedure law. Referring to the bipartite division of the Code of Criminal Procedure, "an erroneous interpretation may not be provided to the meaning of general part and special part of criminal procedure law. This would be a serious error which does no longer be advanced by the doctrine." 6

4 See Decision of the Constitutional Court of Romania Ref. No. 96/2018 [2018-03-01]. Official Journal of Romania, 2018, No. 619.

5 A detailed discussion on the case law presentations regarding the defendants' guarantees during the criminal proceedings is related to the judicial sanction of nullity in cases of changing accusation in the court of the first instance. In this matter, see MAGHERESCU, D. Modificarea învinuirii în prima instanță: Aspecte comparative. 2-a ed. București: Wolters Kluwer, 2016, pp. 194-205. ISBN 978-606-677-017-0; and VOLONCIU, N. Tratat de procedură penală: Partea generală: Partea specială. 2-a ed. București: Paideia, 1996, p. 110. ISBN 973-9131-01-8.

6 See MAGHERESCU, D. Drept procesual penal: Partea generală: Partea specială. 1-a ed. București: Pro Universitaria, 2020, pp. 235-236. ISBN 978-606-26-1267-2. 
The investigation phase is studied within the $9^{\text {th }}$ Chapter. It is featured by the principles of missing publicity, non-contradictority, written procedure and hierarchical subordination. These principles produce legal consequences until a determined moment of the investigation phase, while the contradictority intervenes between accusation and defense during the procedure of submitting and confronting evidence. Moreover, the public feature of this phase is present during realizing the activities of gathering evidence, while the written procedure knows exceptions regarding the hearing of persons that takes place under the principle of orality. Thus, those rules and exceptions characterize the processual institutions and judicial procedures of the investigation phase. There are some processual institutions, such as advancing criminal action, ${ }^{7}$ changing legal qualification of $\mathrm{deed}^{8}$ as well as drawing up the indictment act at the end of the investigation phase.

The $10^{\text {th }}$ Chapter provides a new legal institution regulated by the Code of Criminal Procedure, which was adopted by the Law No. 135 of 2010 on the Code of Criminal Procedure, being in force since the 1 February $2014 .{ }^{9}$ It is about the preliminary courtroom procedure, which supposes an intermediate procedure, preliminary to the judgement in the first instance. The preliminary courtroom's objective is that of verifying legality of the indictment act and administering evidence during the investigation phase. In cases in which the court of law was invested by an indictment act drawn up with the infringement of the provisions of the Code of Criminal Procedure, the judge of preliminary courtroom will state the existence of a case of nullity and the judgment may not be given in such circumstances. The case will then be sent back to the prosecutor, in order to remediate the deficiency.

The judgment of criminal cases in the court of the first instance and the appeal are discussed within the $11^{\text {th }}$ Chapter and the $12^{\text {th }}$ Chapter. In both procedural stages, the common principles of the criminal proceedings are applied: publicity, orality, contradictoriality, intermediation, equality and, last but not least, legality, which characterizes the entire criminal proceedings. In criminal cases, an imperative sequence of carry-

7 See MAGHERESCU, D. Modificarea învinuirii în prima instanță: Aspecte comparative. 2a ed. București: Wolters Kluwer, 2016, pp. 23-40. ISBN 978-606-677-017-0.

8 See MAGHERESCU, D. Modificarea învinuirii în prima instanță: Aspecte comparative. 2a ed. București: Wolters Kluwer, 2016, pp. 77-107. ISBN 978-606-677-017-0.

9 See Law No. 135 of July 1, 2010, on the Code of Criminal Procedure [2010-07-01]. Official Journal of Romania, 2010, No. 486, into force from 1 February 2014. 
ing out procedural acts is observed. It refers to the courtroom session's preliminary acts: judgment investigation, debates, deliberation, pronunciation, elaboration and communication of judicial decision. Regarding the appeals, there are stipulated by the Code of Criminal Procedure the following stages: the ordinary appeal in the Articles 408 - 424 of the Code of Criminal Procedure and the litigation in the Article 425 of the Code of Criminal Procedure. Within the Chapter V of the Title III thereof, the following extraordinary appeals are regulated: litigation of nullity, second appeal in cassation and revision.

Each appeal procedure is presented under the own rules of criminal procedure. The issues on their particularities are taken into consideration, with the specification that the second appeal was abrogated as an ordinary appeal and the new Code of Criminal Procedure regulates the second appeal in cassation as an extraordinary appeal.

The $13^{\text {th }}$ Chapter provides special procedures of the criminal proceedings:

admitting guilt agreement;

litigation on the duration of the criminal proceedings;

procedure on the legal entities' criminal liability;

procedure on the minor offenders, procedure of ordering prosecution;

procedure of restitution of material damages and moral damages in cases of judicial errors or illegal deprivation of liberty;

procedure of international judicial cooperation in criminal matters.

Among them, an important place is dedicated to the special criminal procedure of admitting guilt agreement. Practical issues that the simplified procedure involves are approached both from the jurisprudence's point of view and the doctrinal as well. In this matter, some judicial decisions pronounced by the courts of law in criminal cases, the object of which was admitting guilt agreement signed between the defendant and the prosecutor during the investigation phase, are analysed. Equally, pertinent points of view related to the case law examinations are emphasized. The doctrine has pointed out contradictory opinions regarding the legal entities to achieve the judicial quality as subject of admitting guilt agreement. In this regard, there were advanced two hypotheses: one of them is based on the affirmative thesis, which admits the legal entities' rights to be part of such agreement, while the second one bases on the negative thesis, which admits that the legal entities cannot be part of ad- 
mitting guilt agreement. Regarding the last thesis, Professor Andrei Zarafiu has stated that the law on criminal procedure imposes an implicit interdiction to the legal entities referring to their quality as subject of admitting guilt agreement. 10

Last but not least, the legal doctrine has provided several viewpoints regarding the simplified special procedure in the field of comparative law, which leads to emphasized differences between the legal systems around the world, comparing, in particular, the Romano-Germanic system with the Common-law one. From this perspective, it has been appreciated that there are substantial differences between the inquisitorial legal systems and the adversary legal systems. ${ }^{11}$ Consequently, it has been highlighted the idea that "A succinct analysis of the legal provisions of the other states regarding the procedure of admitting guilt agreement is necessary and useful due to the fact that the current tendency in the legislation of many states is that of unification and the process of unification may be observed only under conditions of knowing every legal provision individually."12 During this process, the degree of implementing special procedure within the legal system is observed. Finally, it should be specified that beyond essential differences in the special procedure of admitting guilt agreement every form regulated by the different states protects procedural guarantees of the participants in the criminal proceedings, with advantages for the defendants, regarding the substantial reduction of criminal punishment for the crime committed.

Taking into consideration the above-stated aspects, it should be appreciated that the presented legal education instrument of criminal procedure law which pays the readers' attention to the most relevant aspects of the criminal proceedings is particularly valuable from both the theoretical point of view and the perspective of analysing the case law presentations. From this reason, it is understood that the theories stated by the theoreticians in criminal matters are often transposed by the practitioners into the process of solving criminal cases. Hence, the new publication Criminal Procedure Law becomes a valuable working instrument

${ }^{10}$ See ZARAFIU, A. Procedură penală: Partea generală: Partea specială. 2-a ed. București: C. H. Beck, 2015, p. 507. ISBN 978-606-18-0412-2.

${ }^{11}$ See PĂCURARIU, I. Aspecte de drept comparat referitoare la acordul de recunoaștere a vinovăției în procesul penal. Revista Universul Juridic. 2020, nr. 9, pp. 45-60. ISSN 23933445.

${ }^{12}$ See PĂCURARIU, I. Aspecte de drept comparat referitoare la acordul de recunoaștere a vinovăției în procesul penal. Revista Universul Juridic. 2020, nr. 9, p. 46. ISSN 2393-3445. 
for the practical side of the criminal proceedings. Thus, the above-discussed legal institutions of the criminal procedure law may sometimes theoretically determine practical solutions of the courts of law. ${ }^{13}$ As a consequence, it is considered that the analysed publication Criminal Procedure Law will be very useful for students of the faculties of law, due to the fact that it may deepen their legal knowledge in such a manner for them to understand the fundamental institutions of the criminal proceedings, principles as well as procedures in particular cases.

\section{References}

Convention for the Protection of Human Rights and Fundamental Freedoms

[European Convention on Human Rights].

Decision of the Constitutional Court of Romania Ref. No. 96/2018 [201803-01]. Official Journal of Romania, 2018, No. 619.

Decision of the High Court of Cassation and Justice of Romania Ref. No. 21/ 2016 [2016-10-11]. Official Journal of Romania, 2016, No. 884.

Law No. 135 of July 1, 2010, on the Code of Criminal Procedure [2010-0701]. Official Journal of Romania, 2010, No. 486, into force from 1 February 2014.

MAGHERESCU, D. Drept procesual penal: Partea generală: Partea specială. 1-a ed. București: Pro Universitaria, 2020. 412 p. ISBN 978-606-261267-2.

MAGHERESCU, D. Modificarea învinuirii în prima instanță: Aspecte comparative. 2-a ed. București: Wolters Kluwer, 2016. 223 p. ISBN 978-606677-017-0.

PĂCURARIU, I. Aspecte de drept comparat referitoare la acordul de recunoaștere a vinovăției în procesul penal. Revista Universul Juridic. 2020, nr. 9, pp. 45-60. ISSN 2393-3445.

VOLONCIU, N. Tratat de procedură penală: Partea generală: Partea specială. 2-a ed. București: Paideia, 1996. 510 p. ISBN 973-9131-018.

ZARAFIU, A. Procedură penală: Partea generală: Partea specială. 2-a ed. București: C. H. Beck, 2015. 545 p. ISBN 978-606-18-0412-2.

\footnotetext{
${ }^{13}$ See MAGHERESCU, D. Modificarea învinuirii în prima instanță: Aspecte comparative. 2a ed. București: Wolters Kluwer, 2016, pp. 81-99. ISBN 978-606-677-017-0.
} 
Assoc. Prof. Djulieta Vasiloi, Ph.D. Institute of Criminal Sciences and Applied Criminology Voluntarilor 8/3 2032 Chișinău Republic of Moldova djuly_v@yahoo.com

(iD) https://orcid.org/0000-0002-7168-8733 